
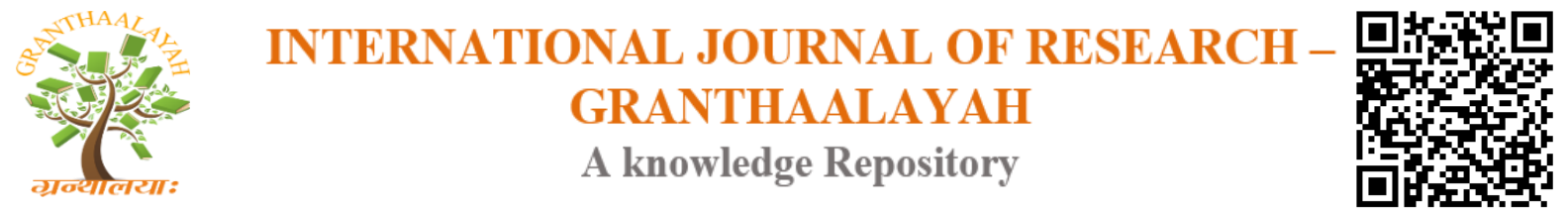

Social

\title{
EFFECTIVENESS OF E - CONTENT ON ACHIEVEMENT IN CHEMISTRY AMONG XI STANDARD BOYS
}

\author{
P. Subramanian ${ }^{1}$, Dr. N. Ramakrishnan ${ }^{2}$ \\ ${ }^{1}$ Ph.D. (Part-Time) Research Scholar, Dept. of Educational Technology, Tamil Nadu Teachers \\ Education University, Chennai, India \\ ${ }^{2}$ Professor and Head, Dept. of Educational Technology, Tamil Nadu Teachers Education \\ University, Chennai, India
}

\begin{abstract}
An innovative application of computer in the teaching and learning process is e-content. This includes text, video, audio, animation and graphics. e-content is the advancement of technology to design, deliver, select, administer and extend learning. e-content in education is a powerful tool that may be used effectively and efficiently within the classroom to create more exciting learning environment and deliver a higher level of educational expertise to students. The present experiment brings out a clear-cut idea about the effectiveness of teaching Chemistry through econtent on the XI Standard boys achievement in Chemistry. The present study reveals that The XI Standard boys in experimental groups of both PPT design and PT design have excelled in econtent on Chemistry (atomic structure) than control groups which had gone through Chemistry (atomic structure) in traditional method in both PPT design and PT design.
\end{abstract}

Keywords: Effectiveness; E-Content; Achievement; Chemistry; XI Standard Boys.

Cite This Article: P. Subramanian, and Dr. N. Ramakrishnan. (2017). "EFFECTIVENESS OF E - CONTENT ON ACHIEVEMENT IN CHEMISTRY AMONG XI STANDARD BOYS." International Journal of Research - Granthaalayah, 5(8:SE), 83-90. https:// doi.org/10.29121/granthaalayah.v5.i8(SE).2017.2262.

\section{Introduction}

An innovative application of computer in the teaching and learning process is e-content. This includes text, video, audio, animation and graphics. e-content is the advancement of technology to design, deliver, select, administer and extend learning. e-content in education is a powerful tool that may be used effectively and efficiently within the classroom to create more exciting learning environment and deliver a higher level of educational expertise to the students. Chemistry, or the central science as it is sometimes called, bridges other natural sciences together. Although chemistry plays a vital role in the world of science, students and teachers in higher secondary education alike have always found difficulty with this particular subject. As students in higher secondary education lose interest in studying chemistry, it is crucial that 
researchers should create innovative technology to increase it. One of the major goals for chemistry teachers is to develop more current methods to teach higher secondary students the necessary concepts in chemistry. The new and improved technological advances have been created to ease the fear of the students and the possible misconceptions they may have about chemistry before even entering the classroom.

\section{Design of the Study}

The study is designed as a Solomon four group experimental design to study the effect of econtent package on Chemistry achievement of XI standard boys. The present study is an experimental study in nature to find out the Effectiveness of e-content on Achievement in Chemistry among XI Standard boys. For this purpose e-content package was developed and validated. The validated e-content package forms as an independent variable of this study. The dependent variable is Student's Achievement in Criterion test on chemistry. In order to find out the achievement in Chemistry among XI standard boys, the investigator developed and standardized a Criterion test on Chemistry for XI standard boys in the unit Atomic Structure. In order to have randomization in the sample the investigator selected two schools in Thoothukudi district. The experimental and control groups were identified in both these schools. Before the treatment both experimental and control groups were equated based on their performances in entry level test. The selected experimental and control groups were administered pre test developed and validated by the investigator. The treatment was conducted in four equal sessions. After the treatments both the groups were administered post test. Data were collected from the students. They were tabulated and applied statistical treatments. .

\section{HYPOTHESIS - 1}

There is no significant difference between experimental group (e-content) boys and control group (Traditional learning) boys in XI Standard students learning in (atomic structure) Chemistry.

\section{SUB HYPOTHESIS - 1.1}

There is no significant difference between the pre test and post test scores of experimental group boys in PPT (Pretest Posttest) design.

Table 1: N, Mean and S.D. Values for the Pre Test and Post Test Scores of Experimental Group Boys in PPT Design

\begin{tabular}{|c|c|c|c|c|c|}
\hline Variables & $\mathbf{N}$ & Mean & S.D. & $\mathbf{T}$ & Significance \\
\hline $\begin{array}{l}\text { PPT(Experimental } \\
\text { Boys) - Pre Test }\end{array}$ & 12 & 13.58 & 3.36 & \multirow{2}{*}{31.986} & \multirow{2}{*}{$\begin{array}{l}\text { Significant } \\
\text { for the df of } 22 \\
\text { at } 0.05 \text { level. } \\
(2.074)\end{array}$} \\
\hline $\begin{array}{l}\text { PPT(Experimental } \\
\text { Boys) - Post Test }\end{array}$ & 12 & 49.41 & 3.02 & & \\
\hline
\end{tabular}

It is evident from the above table that the ' $t$ ' value found out is 31.986 . It is higher than the critical value of 2.074 at 0.05 level. It is significant. Hence, it can be concluded that there exists significant difference between the pre test and post test scores of experimental group boys in the PPT design. The mean value of the post test (49.41) scores of experimental group boys in PPT design is higher than the mean value of pre test (13.58) scores of experimental group boys in 
PPT design. So, the hypothesis stated is rejected. The experimental group boys in PPT design has performed well after the experiment. It can be interpreted that e-content on atomic structure has had a good impact on XI Standard boys' students learning of atomic structure in PPT design.

\section{SUB HYPOTHESIS - 1.2}

There is no significant difference between the pre test scores of control group boys in PPT design and post test scores of control group boys in PPT design.

Table 2: N, Mean and S.D. Values for the Pre Test Scores of Control Group Boys in PPT Design and Post Test Scores of Control Group Boys in PPT Design

\begin{tabular}{|l|l|l|l|l|l|}
\hline Variables & N & Mean & S.D. & T & Significance \\
\hline $\begin{array}{l}\text { PPT(Control Boys) }- \\
\text { Pre Test }\end{array}$ & 12 & 15.50 & 3.08 & $\begin{array}{l}\text { Significant } \\
\text { for the df of 22 } \\
\text { at 0.05 level } \\
(2.074)\end{array}$ \\
\hline $\begin{array}{l}\text { PPT(Control Boys) } \\
\text { Post Test }\end{array}$ & 12 & 35.66 & 2.38 & & 17.941 \\
\hline
\end{tabular}

It is evident from the above table that the ' $t$ ' value found out is 17.941. It is higher than the critical value of 2.074 at 0.05 level. It is significant. Hence, it can be concluded that there exists significant difference between the pre test scores of control group boys in PPT design and post test scores of control group boys in PPT design. The mean value of the post test scores of control group boys (35.66) in PPT design is higher than the mean value of pre test scores of control group boys (15.50) in PPT design. So, the hypothesis stated is rejected. The pre test scores of control group boys in PPT design is lesser than the post test scores of control group boys in PPT design.

\section{SUB HYPOTHESIS - 1.3}

There is no significant difference between the pre test scores of experimental group boys in PPT design and pre test scores of control group boys in PPT design.

Table 3: N, Mean and S.D. Values for the Pre Test Scores of Experimental Group Boys in PPT Design and Pre Test Scores of Control Group Boys in PPT Design

\begin{tabular}{|l|l|l|l|l|l|}
\hline Variables & N & Mean & S.D. & T & Significance \\
\hline $\begin{array}{l}\text { PPT(Experimental } \\
\text { Boys) - Pre Test }\end{array}$ & 12 & 13.58 & 3.36 & 1.437 & $\begin{array}{l}\text { Not Significant } \\
\text { for the df of 22 } \\
\text { at 0.05 level } \\
(2.074)\end{array}$ \\
\hline $\begin{array}{l}\text { PPT(Control Boys) - } \\
\text { Pre Test }\end{array}$ & 12 & 15.50 & 3.08 & & \\
\hline
\end{tabular}

It is evident from the above table that the ' $t$ ' value found out is 1.437. It is lower than the critical value of 2.074 at 0.05 level. It is not significant. Hence, it can be concluded that there exists no significant difference between the pre test scores of experimental group boys and control group boys in PPT design. So, the hypothesis stated is accepted. It can be interpreted that the experimental group boys and control group boys are equated exactly in PPT design.

\section{SUB HYPOTHESIS - 1.4}

There is no significant difference between the post test scores of experimental group boys in PPT design and post test scores of control group boys in PPT design. 
Table 4: N, Mean and S.D. Values for the Post Test Scores of Experimental Group Boys in PPT Design and Post Test Scores of Control Group Boys in PPT Design

\begin{tabular}{|l|l|l|l|l|l|}
\hline Variables & N & Mean & S.D. & T & Significance \\
\hline $\begin{array}{l}\text { PPT(Experimental } \\
\text { Boys) - Post Test }\end{array}$ & 12 & 49.41 & 3.02 & 10.645 & $\begin{array}{l}\text { Significant } \\
\text { for the df of 22 } \\
\text { at } \\
\text { level(2.074) }\end{array}$ \\
\hline $\begin{array}{l}\text { PPT(Control Boys) - } \\
\text { Post Test }\end{array}$ & 12 & 35.66 & 2.38 & .05 \\
\hline
\end{tabular}

It is evident from the above table that the ' $\mathrm{t}$ ' value found out is 10.645 . It is higher than the critical value of 2.074 at 0.05 level. It is significant. Hence, it can be concluded that there exists significant difference between the post test scores of experimental group boys in PPT design and post test scores of control group boys in PPT design. The mean value of the post test scores of experimental group boys (49.41) in PPT design is higher than the mean value of post test scores of control group boys (35.66) in PPT design. So, the hypothesis stated is rejected. The post test scores of control group boys in PPT design is lesser than the post test scores of experimental group boys in PPT design. It can be interpreted that the e-content on atomic structure has had a better impact on XI Standard boys students learning than learning of atomic structure through traditional learning in PPT design.

\section{SUB HYPOTHESIS - 1.5}

There is no significant difference between the post test scores of experimental group boys in PT design and post test scores of control group boys in PT (Post test only) design.

Table 5: N, Mean and S.D. Values For the Post Test Scores of Experimental Group Boys in PT Design and Post Test Scores of Control Group Boys in PT Design

\begin{tabular}{|l|l|l|l|l|l|}
\hline Variables & N & Mean & S.D. & T & Significance \\
\hline $\begin{array}{l}\text { PT(Experimental } \\
\text { Boys) - Post Test }\end{array}$ & 10 & 36.70 & 1.63 & 20.125 & $\begin{array}{l}\text { Significant } \\
\text { for the df of } 18 \\
\text { at } 0.05 \quad l e v e l \\
(2.101)\end{array}$ \\
\hline $\begin{array}{l}\text { PT(Control } \\
\text { Boys) - Post Test }\end{array}$ & 10 & 24.70 & 0.48 & & \\
\hline
\end{tabular}

It is evident from the above table that the ' $t$ ' value found out is 20.125 . It is higher than the critical value of 2.101 at 0.05 level. It is significant. Hence, it can be concluded that there exists significant difference between the post test scores of experimental group boys in PT design and post test scores of control group boys in PT design. The mean value of the post test scores of experimental group boys (36.70) in PT design is higher than the mean value of post test scores of control group boys (24.70) in PT design. So, the hypothesis stated is rejected. The post test scores of control group boys in PT design is lesser than the post test scores of experimental group boys in PT design. It can be interpreted that the e-content on atomic structure has had a better impact on XI Standard boys students learning than learning of atomic structure through traditional learning in PT design.

\section{SUB HYPOTHESIS - 1.6}

There is no significant difference between the pre test scores of control group boys in PPT design and post test scores of control group boys in PT design. 
Table 6: N, Mean and S.D. Values for the Pre Test Scores of Control Group Boys in PPT Design and Post Test Scores of Control Group Boys in PT Design

\begin{tabular}{|l|l|l|l|l|l|}
\hline Variables & N & Mean & S.D. & T & Significance \\
\hline $\begin{array}{l}\text { PPT(Control Boys) - } \\
\text { Pre Test }\end{array}$ & 14 & 15.50 & 2.90 & 12.362 & $\begin{array}{l}\text { Significant } \\
\text { for the df 26 } \\
\text { at 0.05 level } \\
(2.056)\end{array}$ \\
\hline $\begin{array}{l}\text { PT(Control Boys) - } \\
\text { Post Test }\end{array}$ & 14 & 25.35 & 1.27 & & \\
\hline
\end{tabular}

It is evident from the above table that the ' $\mathrm{t}$ ' value found out is 12.362 . It is higher than the critical value of 2.056 at 0.05 level. It is significant. Hence, it can be concluded that there exists significant difference between the pre test scores of control group boys in PPT design and post test scores of control group boys in PT design. The mean value of the post test scores of control group boys (25.35) in PT design is higher than the mean value of pre test scores of control group boys (15.50) in PPT design. So, the hypothesis stated is rejected. The pre test scores of control group boys in PPT design is lesser than the post test scores of control group boys in PT design. It can be interpreted that it reflects the normal difference between the scores of XI Standard boys students after the subject has been taught and the XI Standard boys students scores before the subject has been taught.

\section{SUB HYPOTHESIS - 1.7}

There is no significant difference between the post test scores of experimental group boys in PPT design and post test scores of experimental group boys in PT design.

Table 7: N, Mean and S.D. Values for the Post Test Scores of Experimental Group Boys in PPT Design and Post Test Scores of Experimental Group Boys in PT Design

\begin{tabular}{|l|l|l|l|l|l|}
\hline Variables & N & Mean & S.D. & T & Significance \\
\hline $\begin{array}{l}\text { PPT(Experimental } \\
\text { Boys) - Post Test }\end{array}$ & 10 & 49.60 & 3.23 & 11.727 & $\begin{array}{l}\text { Significant } \\
\text { for the df of 18 } \\
\text { at 0.05 level } \\
(2.101)\end{array}$ \\
\hline $\begin{array}{l}\text { PT(Experimental } \\
\text { Boys) - Post Test }\end{array}$ & 10 & 36.70 & 1.63 & & \\
\hline
\end{tabular}

It is evident from the above table that the ' $t$ ' value found out is 11.727. It is higher than the critical value of 2.101 at 0.05 level. It is significant. Hence, it can be concluded that there exists significant difference between the post test scores of experimental group boys in PPT design and post test scores of experimental group boys in PT design. The mean value of the post test scores of experimental group boys (49.60) in PPT design is higher than the mean value of post test scores of experimental group boys (36.70) in PT design. So, the hypothesis stated is rejected. The post test scores of experimental group boys in PT design is lesser than the post test scores of experimental group boys in PPT design. It can be interpreted that both experimental group boys have had a good impact in learning atomic structure through e-content. However, the pre test and post test effect in PPT design has influenced the XI Standard boys students scores more than the scores of XI Standard boys students in PT design.

\section{SUB HYPOTHESIS - 1.8}

There is no significant difference between the post test scores of control group boys in PPT design and post test scores of control group boys in PT design. 
Table 8: N, Mean and S.D. Values for the Post Test Scores of Control Group Boys in PPT Design and Post Test Scores of Control Group Boys in PT Design

\begin{tabular}{|l|l|l|l|l|l|}
\hline Variables & N & Mean & S.D. & T & Significance \\
\hline $\begin{array}{l}\text { PPT(Control Boys) - } \\
\text { Post Test }\end{array}$ & 14 & 35.78 & 2.29 & $\begin{array}{l}\text { Significant } \\
\text { for the of 26 } \\
\text { at 0.05 level } \\
(2.056)\end{array}$ \\
\hline $\begin{array}{l}\text { PT(Control Boys) - } \\
\text { Post Test }\end{array}$ & 14 & 25.35 & 1.27 & & \\
\hline
\end{tabular}

It is evident from the above table that the ' $t$ ' value found out is 17.393. It is significant. Hence, it can be concluded that there exists significant difference between the post test scores of control group boys in PPT design and post test scores of control group boys in PT design. The mean value of the post test scores of control group boys (35.78) in PPT design is higher than the mean value of post test scores of control group boys (25.35) in PT design. So, the hypothesis stated is rejected. The post test scores of control group boys in PT design is lesser than the post test scores of control group boys in PPT design. It can be interpreted that the groups are equated correctly. It can be interpreted that both control group boys have had a good impact on learning atomic structure through traditional learning. However, the pre test and post test effect in PPT design has influenced the XI Standard boys students scores more than the scores of XI Standard boys students in PT design.

\begin{tabular}{|c|c|c|}
\hline Variables & Significance & Remarks \\
\hline PPT(Experimental) - Pre Test & \multirow{2}{*}{ Significant } & \multirow{2}{*}{$\begin{array}{l}\text { PPT(Experimental) - Post Test } \\
> \\
\text { PPT(Experimental) - Pre Test }\end{array}$} \\
\hline PPT(Experimental) -Post Test & & \\
\hline PPT(Control) -Pre Test & \multirow{2}{*}{ Significant } & \multirow{2}{*}{$\begin{array}{l}\text { PPT }(\text { Control }) \text { - Post Test } \\
> \\
\text { PPT }(\text { Control }) \text { - Pre Test }\end{array}$} \\
\hline PPT(Control) - Post Test & & \\
\hline PPT(Experimental) - Pre Test & \multirow{2}{*}{$\begin{array}{l}\text { Not } \\
\text { Significant }\end{array}$} & \multirow{2}{*}{$\begin{array}{l}\text { PPT(Experimental }) \text { - Pre Test } \\
= \\
\text { PPT }(\text { Control }) \text { - Pre Test }\end{array}$} \\
\hline PPT(Control) - Pre Test & & \\
\hline PPT(Experimental) - Post Test & \multirow{2}{*}{ Significant } & \multirow{2}{*}{$\begin{array}{l}\text { PPT(Experimental) - Post Test } \\
> \\
\text { PPT }(\text { Control }) \text { - Post Test }\end{array}$} \\
\hline PPT(Control) - Post Test & & \\
\hline PT(Experimental) - Post Test & \multirow{2}{*}{ Significant } & \multirow{2}{*}{$\begin{array}{l}\text { PT(Experimental) - Post Test } \\
> \\
\text { PT }(\text { Control }) \text { - Post Test }\end{array}$} \\
\hline PT(Control) - Post Test & & \\
\hline PPT(Control) - Pre Test & Significant & PT(Control) \\
\hline
\end{tabular}




\begin{tabular}{|c|c|c|}
\hline PT(Control) - Post Test & & $\begin{array}{l}> \\
\text { PPT(Control) - Pre Test }\end{array}$ \\
\hline PPT(Experimental) - Post Test & \multirow{2}{*}{ Significant } & \multirow{2}{*}{$\begin{array}{l}\text { PPT(Experimental) - Post Test } \\
> \\
\text { PT(Experimental) - Post Test }\end{array}$} \\
\hline PT(Experimental) - Post Test & & \\
\hline PPT(Control) - Post Test & \multirow{2}{*}{ Significant } & \multirow{2}{*}{$\begin{array}{l}\text { PPT(Control) - Post Test } \\
> \\
\text { PT }(\text { Control }) \text { - Post Test }\end{array}$} \\
\hline PT(Control) - Post Test & & \\
\hline
\end{tabular}

Figure 1: Chart Showing the Solomon Four Group Analysis - Boys

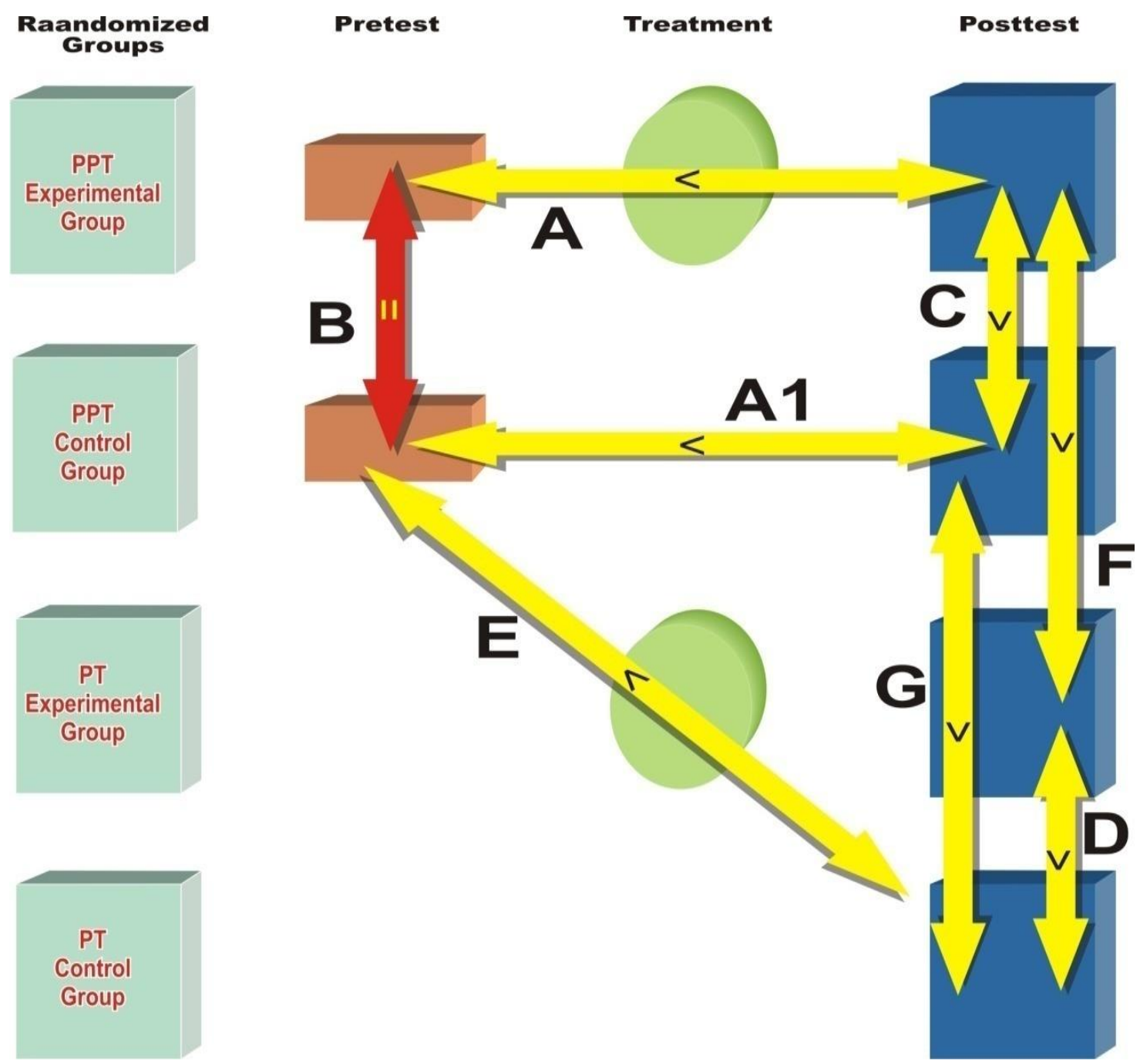

Figure 2: Graph Showing the Solomon Four Group Analysis - Boys

A - PPT Experimental Group pre test (vs) PPT Experimental Group post test

A1 - PPT Control Group pre test (vs) PPT Control Group post test

B - PPT Experimental Group pre test (vs) PPT Control Group pre test 


\section{C - PPT Experimental Group post test (vs) PPT Control Group post test \\ D - PT Experimental Group post test (vs) PT Control Group post test \\ E - PPT Control Group pre test (vs) PT Control Group post test \\ F - PPT Experimental Group post test (vs) PT Experimental Group post test \\ G - PPT Control Group post test (vs) PT Control Group post test}

\section{Conclusion}

It is evident from fig 1 and 2 that the XI Standard boys in experimental groups of both PPT design and PT design have excelled in e-content on Chemistry (atomic structure) than control groups which had gone through Chemistry (atomic structure) in traditional method in both PPT design and PT design.

It is evident from the findings that the post test scores of XI Standard boys in both experimental and control groups are higher than their pre test scores in PPT design. It implies that both econtent and traditional method have had an impact on XI Standard boys' learning of Chemistry. It is proved from the findings that the pre test scores of XI Standard boys in both experimental and control groups of PPT design are equal. It implies that XI Standard boys in both experimental and control groups are equal in their academic achievement. The researcher has properly equated the groups.

A cross comparison of the findings reveals that the post test scores of XI Standard boys in control group of PT design are higher than the pre test scores of XI Standard boys in control group of PPT design. It implies that the traditional teaching has had an effect on XI Standard boys' learning of Chemistry.

It is evident from the findings that the post test scores of XI Standard boys in control group of PPT design are higher than the post test scores of XI Standard boys in control group of PT design. In the same way, the post test scores of XI Standard boys in experimental group of PPT design are higher than the post test scores of XI Standard boys in experimental group of PT design. It is due to the pre test effect on both experimental and control group boys in PPT design.

\section{References}

[1] Aggarwal, Y. P. (2002). Statistical Methods. New Delhi: Sterling Publishers Private Limited.

[2] Best, J. W., \& Khan, J. V. (2012). Research in Education. New Delhi: Prentice Hall of India Private Limited.

[3] Bhatnagar (2005). Readings in Methodology of research in Education. Meerut: R.Lall Book Depot.

[4] Chandha, S. (2000). Principle of Education. New Delhi: International Publishing House.

[5] Deepak, K. \& Srivastava (2005). E-learning: A new way of education. University News.

[6] Karpagakumaravel. (1999). Readings in Educational Technology. Coimbatore: Suri Publishers. 